\title{
20 \\ COVID-19 OUTBREAKS AND IMPACT ON DRINKING WATER
}

\author{
Sneha Khadse ${ }^{1}$, Nisha Gharami², Triveni Sapate ${ }^{3}$ \\ E-Mail Id: khadsesneha43@gmail.com, nishagharami5@gmail.com,trivenisapate02@gmail.com \\ ${ }^{1}$ Project Assistant, CSIR NEERI Nagpur, Maharastra, India \\ ${ }^{2}$ Medical Records Executive, Vitality BSS, Mumbai, Maharastra, India \\ ${ }^{3}$ Kamla Nehru Mahavidyalaya, Nagpur, Maharastra, India
}

Abstract-The study of COVID-19 outbreaks and its impact on drinking water which necessary for our life. Membrane filtration methods used for the purification of water, in this method water from different samples are passed through a membrane filter with a pore size of 0.45 micro meter and the membrane is incubated on an agar plate. Bacterial cells trapped on membrane filter will grow into colonies that can be counted, and bacterial density of the water samples can be calculated. Finally, we know that if water gets contaminated with the fecal matter then disinfect the water by chlorination or UV system.

Keywords: Corona virus, E.coli, fecal coliform, MFT.

\section{INTRODUCTION}

The COVID-19 pandemic, also known as the coronavirus pandemic, is an ongoing pandemic of coronavirus disease 2019 (COVID-19), caused by severe acute respiratory syndrome coronavirus 2 (SARS-CoV-2). The outbreak was first spotted in Wuhan, China, in December 2019. The World Health Organization proclaimed the outbreak a Public Health Emergency of International suspicion on 30 January, and a pandemic on 11 March.As of 17 May 2020 , more than 4.71 million cases of COVID-19 have been reported in more than 188 countries and territories, resulting in more than 315,000 deaths. More than 1.73 million people have recovered.The virus is primarily sweeping between people during close contact, most often via small droplets elicited by coughing, sneezing, and talking. The droplets conventionally plunge to the ground or onto surfaces rather than extents less typically, people may become debased by touching a tainted surface and then touching their face.

It is most epidemic while the first three days thereupon the onslaught of symptoms, although the spread is possible before symptoms arise, and from people who do not show any symptoms. Common symptoms involved fatigue, shortness fever, cough, and breath, loss of smell. Complications may entail syndrome and pneumonia. The time from exposure to an onslaught of symptoms is generally around five days and might range from 2 to 14 days. Yet there is no known vaccine or specific treatment.

The first treatment is symptomatic and treatment. The virus is too normally hauled in microscopic water droplets, or aerosols, which enter to the air through evaporation or spray. "The ongoing Covid-19 pandemic highlights the urgent need for a careful evaluation of the fate and control of this contagious virus in the environment," said the University of California researcher Haizhou Liu. "Environmental engineers like us are well-positioned to apply our expertise to address these needs with international collaborations to protect public health.”During a 2003 SARS outbreak in Hong Kong, a sewage leak caused a cluster of cases through aerosolization.

Although this has not occurred during the current pandemic so far, its similarities to SARS mean this infection route could be possible. It is also thought Covid-19 could colonize biofilms that line drinking water systems, making showerheads a possible source of aerosolized transmission. This transmission pathway is already thought to be a major source of exposure to the bacteria that causes Legionnaire's disease. Most water treatment routines are thought to kill or remove coronaviruses effectively in both drinking and wastewater. Oxidation with hypochlorous acid or peracetic acid, and inactivation by ultraviolet irradiation, as well as chlorine, are thought to be enough to eradicate the virus. COVID-19 detected in feces:- some coronavirus including SARS-CoV(2002), have the capability of binding to human cells in both the lung and the intestine. Bind to receptor protein ACE2 on human cells that are present in various human organs and are abundant in the lung and small intestine.

COVID-19 RNA was detected in raw wastewater at the Amsterdam airport and at a wastewater treatment plant in the Netherlands. Active COVID-19 as detected in the feces of a confirmed case in China. COVID -19 patients can have a live virus in stool specimens. So the virus could be transmitted through the potential fecal-oral-route and through the water. Persistence of coronavirus in water, coronavirus seems to remain infective longer in colder water than in warmer water, human viruses do not replicate in environment.

\section{METHOD AND MATERIAL}

\subsection{Materials}

Membrane filtration assembly, M-endo and M-Fc media using sterile forcesps, place a sterile blotter pad in the bottoms of petri plates for the m-endobroth-MF.Pipette $2 \mathrm{ml}$ of $\mathrm{m}$-endo broth $-\mathrm{MF}$ onto each pad and replace covers.

DOI Number: https://doi.org/10.30780/IJTRS.V05.I08.005

pg. 35

WWW.ijtrs.com

WWW.ijtrs.org

Paper Id: IJTRS-V4-I7-003

@ 2017, IJTRS All Right Reserved

Volume V Issue VIII, August 2020 


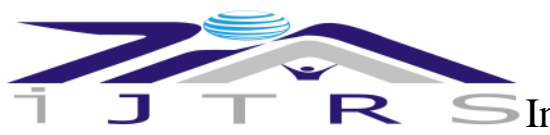

International Journal of Technical Research \& Science

Alternatelyprepare m-FC agar plate.Assemble the filter funnel on the flask. Place a sterile membrane filter using sterile forceps with grid side up. Center the filter.Add buffer if necessary and then add the prescribed volume of sample. Filter under gentle vaccum.with the vacuum still applied, remove the filter with sterile forceps.Place the filter paper on the appropriate medium prepared before. The m-endo plates keep inverted and incubate at $370 \mathrm{C}$ for 24 to 48 hours and m-FC plate keep at $440 \mathrm{C}$ for 24 hours.After incubation, count the colonies to determine the concentration of organisms in the original water sample.Pink colour colonies show on m-endo plate and blue colour colonies shows on M-fc plate. Report the result as CFU/100ml.

\subsection{Collection of Sample}

After collecting the sample, leave adequate $2.5 \mathrm{~cm}$ air space in the bottle least to simplify mixing by shaking, before the examination. Collect samples that are delegate of the water being checked, flush or disinfect sample ports, and use aspects method to avoid sample contamination. Take samples from reservoirstream a river, lake, orby clenching the bottle near its floor in the hand and falling over it, inlet downward, beneath the surface. Turn bottle until inlet points barely upward and mouth is overseen toward the flow. If there is no flow, as in case of a reservoir, create a flow artificially by tugging bottle forward face down in a direction away from the hand.

\section{CHARACTERIZATION OF BACTERIA}

\subsection{Morphological Characteristics}

Both Morphological and cultural traits of strain were studied by inoculating strain into sterile media such as yeast malt extract agar. The media were sterilized then poured into sterile Petridishes. Now the Solidified media, culture of the selected strain streaked and incubated at $27^{\circ} \mathrm{c}$ for 7 days.

\subsection{Microscopical Characterization}

\subsubsection{Gram Staining Method}

A smear of the strain was prepared on a clean glass slide and the smear was allowed to air dry and heat fixed it. the heat fixed smear was flooded with crystal violet and after one minute, washed with water then flooded with mordant gram's iodine. the smear was decolorized by using $95 \%$ ethyl alcohol, washed with water and then stained with safranin (counter stain) for $45 \mathrm{sec}$. after washing with water, the smear was clear with tissue paper and analyzes lesser oil immersion (100x).

\subsubsection{Motility}

The motility is an essential in identification of bacteria. Motility of the given isolates, was observed by using 'Hanging drop Method' as per standard protocol. On the basis of motility, the microbes were observed for their motility as non-motile, sluggishly motile, actively motile or highly motile. The bacterial isolates were farther heeded for biochemical characteristics.

\subsection{Biochemical Characteristics}

\subsubsection{Sugar Fermentation Test}

The bacterial isolates were assessed for their ability to used various kind of sugars such as glucose, lactose, sucrose and mannitol as a source of carbon and energy to be tested production of gas. The sugar to be assessed was added in peptone water medium to the concentration of $1 \%$ and autoclaved. The isolated was inoculated and incubated in at $37^{0} \mathrm{c}$ for 24 hours.

\subsubsection{Indole Test}

This test is accomplished to discern the ability of an organism to ripindole from tryptophan molecule. Certain organism are capable of hydrolyzing and deaminating the amino acid tryptophan that intervene the production of indole. Tryptone water a mediam for glimpse of indole production which is rich in tryptophan was inoculated with the bacterial isolate and incubated at $37^{\circ} \mathrm{c}$ for 24 hour .finally few drops of kovac's reagent was added then tube was perceive for formation of red coloured ring. The presence of red colour ring gives positive test wand absence gives negative test respectively.

\subsubsection{Methyl Red Test}

This test provides a significant key for the identification of bacteria that produce strong acid from glucose as well as can maintain low $\mathrm{pH}$ after elongated incubation by the buffering system. Now Two drops of methyl red reagent were added after $24 \mathrm{hrs}$ of incubation at 370c. The colour change of medium to bright red colour due to the addition of methyl red indicator. It shows a positive test extent no change in colour shows a negative test.

\subsubsection{Vogus Proskauer Test}

This test is used to assess the production of acetyl methyl carbinol. The tube incorporates glucose phosphate broth was inoculated with bacterial isolate and incubated at 370.c for 24 hours. Subsequently, incubation about $0.6 \mathrm{ml}$ of

$$
\begin{aligned}
& \text { www.ijtrs.com } \\
& \text { www.ijtrs.org }
\end{aligned}
$$




\section{ᄀ $\mathbb{R} \leqq$ International Journal of Technical Research \& Science}

alpha naphthol solution came after by $0.2 \mathrm{ml}$ of $40 \% \mathrm{KOH}$ solution was added to $2.5 \mathrm{ml}$ of incubated broth. The tubes were shaken well and kept for 10-15 min. The positive tests indicated by the development of red colour thereafter the addition of Barritt's reagent. The red colour is due to the production of acetyl methyl sorbitol. The formation of red colour gives a positive test and no change in colour gives a negative test.

\subsubsection{Citrate Utilization Test}

This test is performed to assume the ability of an organism to use sodium citrate as a sole source of carbon for metabolism and growth. Koser's citrate broth which is bare of protein and carbohydrate. Exempt citrate was inoculated by an organism and incubated at 370c for 24 hours. The broth used for the test was Koser's citrate broth which contains bromothymol blue indicator which is yellow at acidic $\mathrm{pH}$ green at neutral $\mathrm{pH}$ and blue at alkaline $\mathrm{pH}$. Blue colour indicates a positive test while the absence of blue colour indicates a negative test.

\subsubsection{Urease Test}

This test is manipulated to infer the production of enzyme urease by micro-organism. For this test urea agar base is used. It contains urea which gets hydrolyzed by the growing bacteria. Hydrolysis of urea results in the formation of ammonia, which is identified by the change in colour from yellow to pink because of the indicator, integrates into the medium that is phenol red. The urea agar base slant was inoculated with the bacterial isolation and was incubated at 370c for 24 hours. After 24 hours the appearance of pink colour shows a positive test while no change in colour shows a negative test.

\section{DRINKING WATER TREATMENT CONSIDERATIONS}

Surface water treatment plants with upstream wastewater impacts may be defenceless to the presence of coronavirus in the raw water supply during and after an outbreak. Ensure the disinfection performance is continuously regulated, disinfection dose, disinfection residual, temperature, flow, turbidity, $\mathrm{pH}$.

\section{RESULT AND DISCUSSIONS}

By performing the MFT method we know the bacterial count, and using the following formula we know the coliform density in the water.

Coliform density $=$ counted colonies $\mathrm{x} 100 / \mathrm{ml}$ of sample filtered

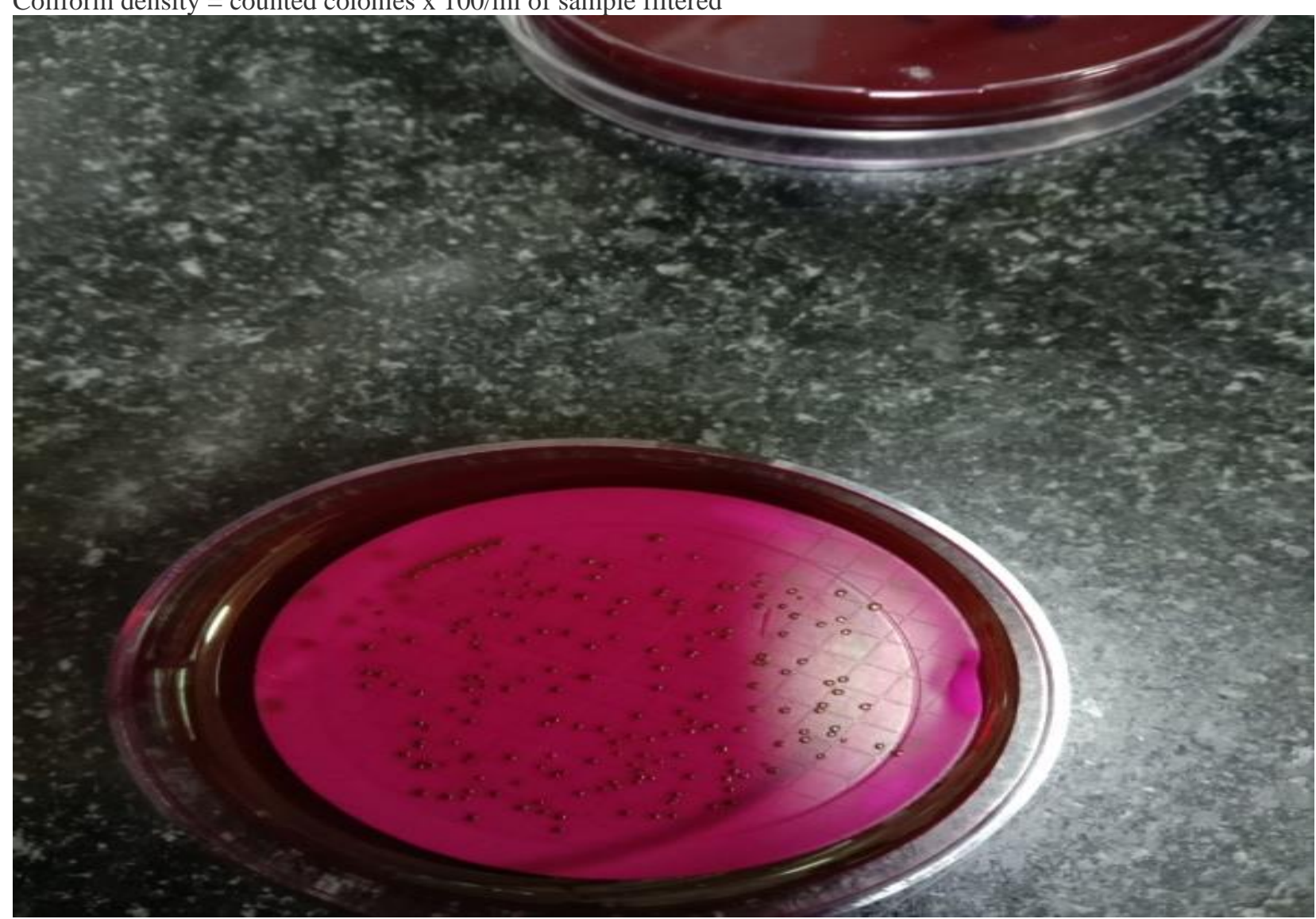

Fig. 5.1 Coliform on M-Endo Plate

DOI Number: https://doi.org/10.30780/IJTRS.V05.I08.005

pg. 37

www.ijtrs.com

www.ijtrs.org

Paper Id: IJTRS-V4-I7-003

Volume V Issue VIII, August 2020

@ 2017, IJTRS All Right Reserved 


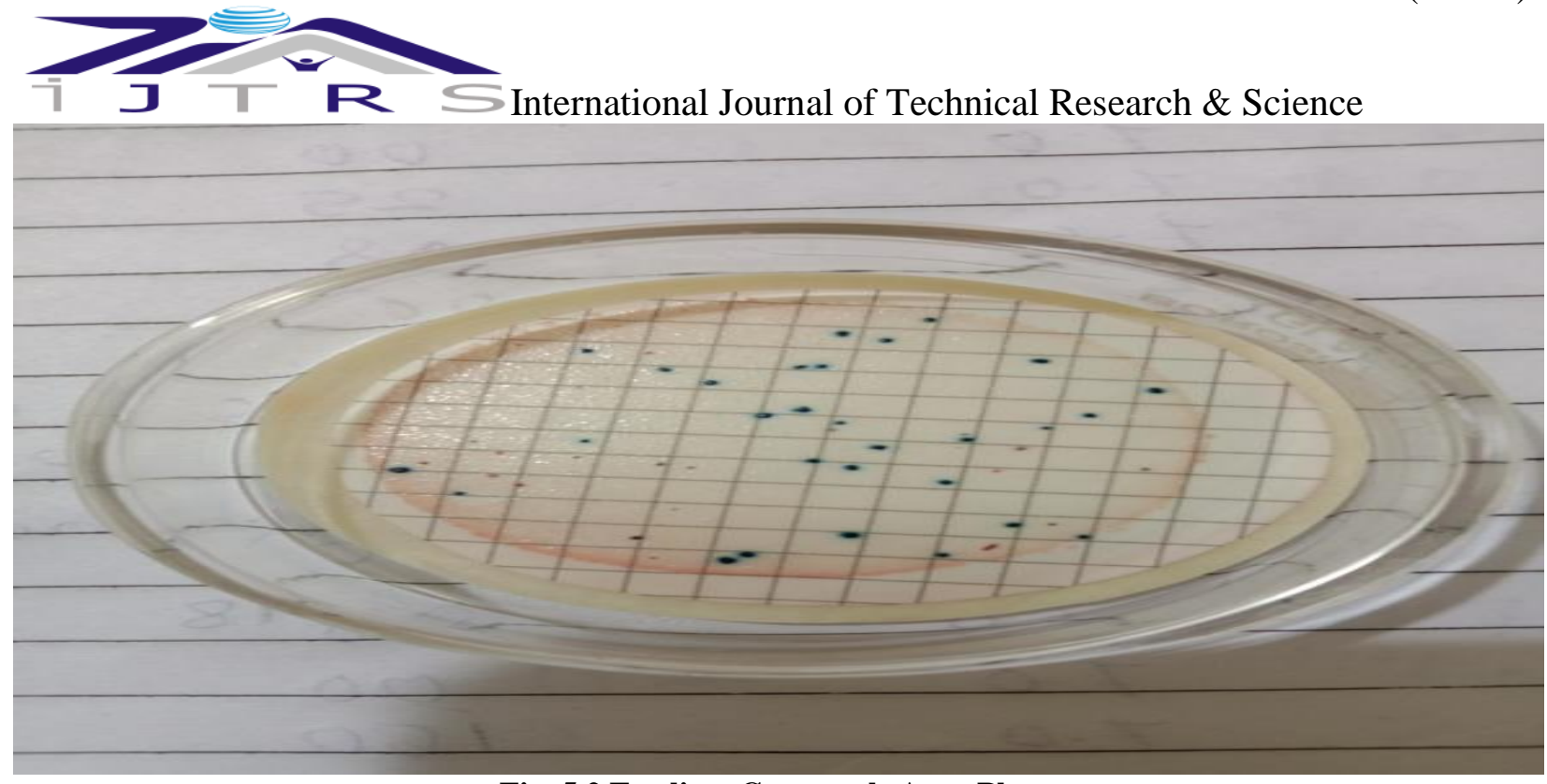

Fig. 5.2 E.coli on Cromocult Agar Plate

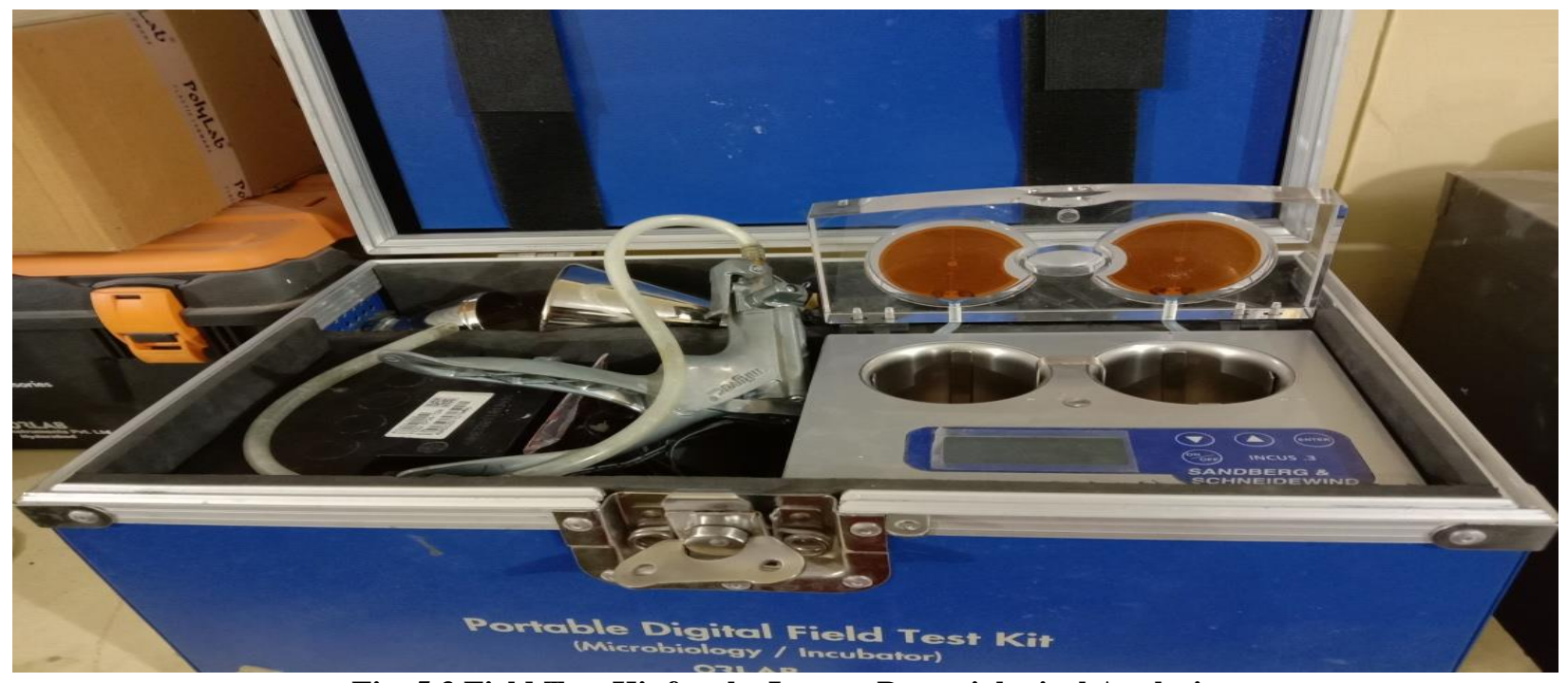

Fig. 5.3 Field Test Kit for the Instant Bacteriological Analysis

\subsection{Treatment of Water}

The recommended disinfection system can be utilized to assess six varied operation schemes. By using the combination of ozonation, UV irradiation, and chlorination with sodium hypochlorite based on effluent water quality, the benefit of each disinfection technology among distinct technologies can be fully realized. Observation of Research implies that ozonation results in a 20-30\% increase in UV transmittance of the water, another one the UV dose can be decreased. During the COVID-19 outbreak, ozone and UV doses were modified to attain a high level of disinfection and the residual chlorine concentration was relatively stable, plying less adverse impact from chlorination. The communal disinfection practice obtains $99.99 \%$ inactivation of faecal coli form; faecal coli form concentration in the disinfected effluent was beneath detection (detection limit is 2 CFU/L). No COVID-19 was observed in the effluent after disinfection. Chlorine residual in the discharge was low $(<0.1 \mathrm{mg} \mathrm{Cl2} / \mathrm{L})$. The use of cooperative disinfection technologies has ascertained that the strategy is not only effective in inactivating pathogens, but also flexible, robust, and stable. Furthermore, it can be operated in a cost-effective manner. We tested the virus concentration of the effluent from the sewage treatment plant. No COVID-19 was detected in the effluent after disinfection. Water and wastewater management has asserted to be a believable and important factor of our societies and an essence contribution to public health even during a virus related pandemic. The utilities' first response to the outbreak by bolstering the disinfection dosages has been the core step in protection and prevention of both the utility employees and the receiving water environment and minimalises the potential spread of the virus. If contamination does occur, analysts should then recognize the inappropriate in their own method and question their own work accordingly. Similarly, samples known to be contaminated may be refound to provide a crude positive control. 
7 ] $\mathrm{T}$ S International Journal of Technical Research \& Science

Equipment review. A commitment to decentralized testing with field test kits and other convenient equipment normally results in a larger quantity of equipment being in use. Regular review of the equipment (e.g. temperature checking of incubators) is important. To ensure standardization, this should be attempted by supervisory staff from a controlled laboratory. Guidelines for drinking-water quality are the applicability of technique under field conditions should be analyzed by a central laboratory. Safety The safety of staff undertaking analytical procedures, both in the field and in the laboratory, is of the biggest importance. All staff should be trained in safety procedures related to their work. In the laboratory, individual staff members should be authorized to undertake procedures involving risk of any type only after suitable training; unauthorized staff should not be permitted to undertake analyses. All laboratories should formulate and appliance a safety policy that should cover cleaning, disinfection, and the containment of hazardous substances. Safety equipment such as fire extinguishers, safety glasses, and first-aid kits should be suitably located, and readily available; they should be routinely tested and all staff should be skilled in their use.

Single Stranded RNA genome of SARS CoV-2 ( 30kb length)

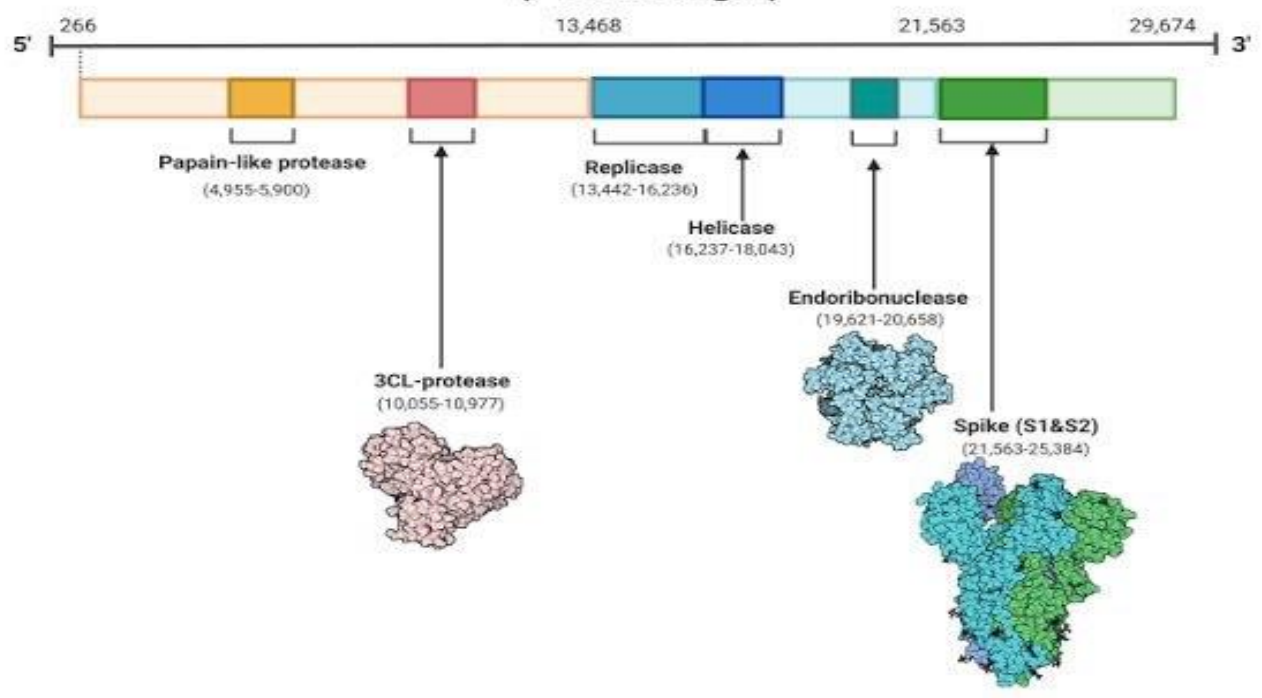

Fig. 5.4 Single Stranded RNA Gemone of SARS CoV-2

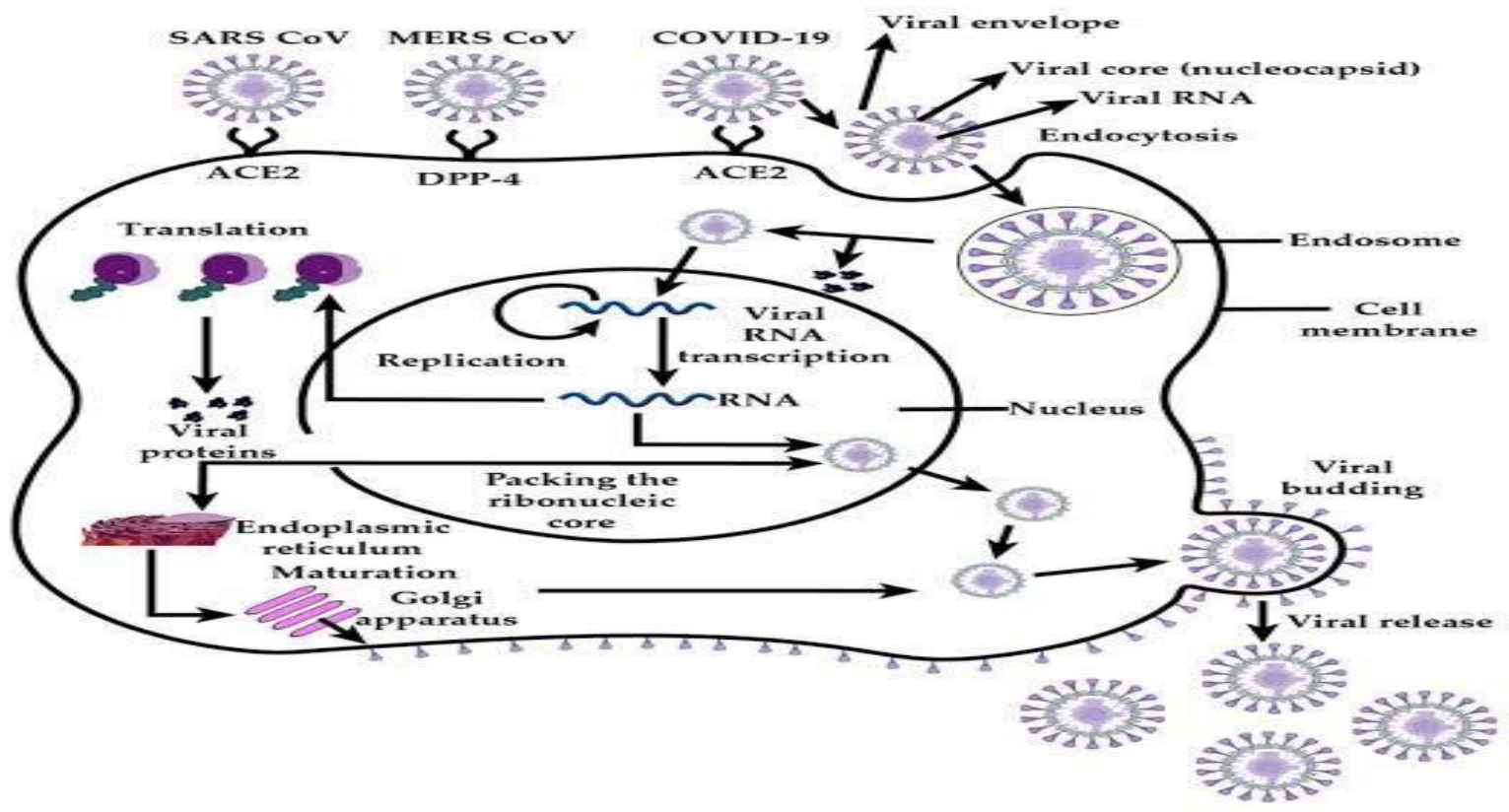

Fig. 5.5 SARS CoV Entry in Cell 


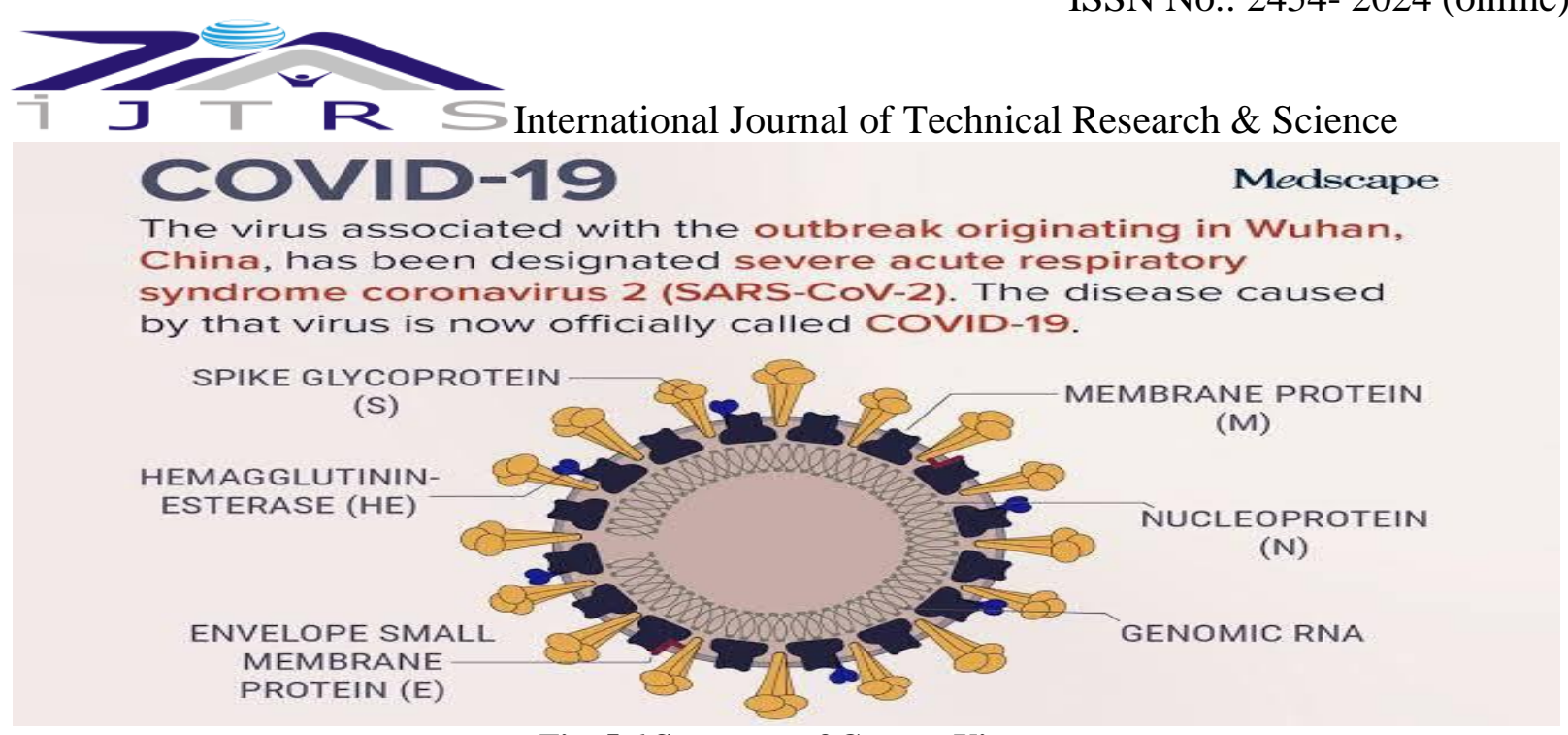

Fig. 5.6 Structure of Corona Virus

\section{CONCLUSIONS}

Optimized conventional filtration can achieve $2 \operatorname{logs}(99 \%)$ virus removals. Chlorination at a level typically used for controlling viruses in general (example-4log inactivation) are expected to be effective for COVID 19 infectious coronavirus may be present in raw wastewater collected from an infected population. Coronavirus may remain infective for a few days if present in raw wastewater. The quantity, persistency, and risk to human health from COVID-19 in raw wastewater are currently unknown.

\section{REFERENCES}

[1] Sneha khadse, project assistant at CSIR NEERI, Nagpur Study of bacteriological and chemical analysis of all blocks of basti district U.P, 2020, Volume 9: issue 6:1913-1920.

[2] Isolation of antibiotic producing actenomycetes from soil, 2020, sneha khadse, project assistant, CSIR NEERI Nagpur, and priyanka titirmare , kamla Nehru mahavidyalaya, Nagpur, 7(5):, 481-487:

[3] Martone RS, Martins BE, Peternella SF, Razzolini M, Tereza P. Assessment of the Bacteriological Quality of the Drinking Water Consumed in a Condominium of

[4] Priorities for environmental sanitation interventions based on epidemiological criteria: A Brazilian study. J. Water Health. 2005; 3(3): 271-281. Students.Sch. Acad. J. Biosci. 2014; 2(9): 564-569,Cairncross S, Blumenthal U, Kolsky P, Moraes L,

[5] World Health Organization (WHO).International Standards for Drinking Water. 1985, pp 10-15

[6] Tayeh A. The public and domestic domains in the transmission of disease.Trop Med Int Health. 1996 Feb; 1(1):27-34.

[7] Steiner TS, Samie A, Guerrant RL. Infectious diarrhea: new pathogens and new challenges in developed and developing areas. Clin Infect Dis. 2006 Aug 15; 43(4): 408-10. Epub 2006 Jul

[8] Javed A, Arshad H, Hamida A. The occurrence of coliforms bacteria in water reservoir at different schools of district Peshawar.J. Biochem. Mol. Biol. 2011; 44: 64-67

[9] Adetunde L, Glover RL. Bacteriological Quality of Borehole Water Used by Students' of University for Development Studies, Navrongo Campus in Upper-East Region of Ghana.Current Research Journal of

[10] Malhotra S, Arora U, Devi P. How safe is the safe water supply? The internet journal of Microbiology. 2009; 7 (1): 27-31, Biological Sciences. 2010; 2(6): 361-364.

[11] Goel S, Sood R, Mazta S, Bansal P, Gupta A.

[12] Stephen TO, Joseph KA. Escherichia coli as an indicator of bacteriological quality of water: an overview. Microbiol Res. 2013; 4 (2): 5-11.

[13] Bacteriological quality of water samples of a tertiary care medical centre campus in North West Himalayan region of India. Internet journal of Third world Medicine. 2007; 5(1): 5.

[14] World Health Organization. 2010. Guidelines for drinking water quality. http://www.who.int/ water sanitation_health /WHS_WWD2010_guidelines_2010.Pdf accessed 8.11.2015.

[15] Kravitz JD, Nyaphishi M, Mandel R, Petersen E. Quantitative bacterial examination of domestic water supplies in the Lesotho Islands: water quality, sanitation and village health. Bulletin of world health.

[16] Tillett HE. Most probable numbers of organisms: Organization. 1999; 77 (10): 829-836.

[17] Revised tables for the multiple tube method.Epidemiol Infect. 1987 Oct; 99(2):471-6.

[18] Sinha SK. Contamination in some rural ponds water of Muzzarpur (Bihar). Pollution Research.1991; 10 (3). 
7 ] $\mathrm{R} \leqq$ International Journal of Technical Research \& Science

[19] Senior BW. Examination of water, milk, food and 179-182. Air. pp. 883-921. In: Collee J.G., Fraser A.G., Marmion

[20] Ramteke PW, Gaur A, Pathak SP, Bhattacharjee JW.Antibiotic resistance of coliforms in drinking water in rural areas. Indian J Med Res. 1990 May; 91:185-8. "Research and Demonstration of Key Treatment Technologies for Enhancement of Reclaimed Water Quality in Beijing."

[21] Hunter PR, Fewtrell L. 2001. In: Water quality: Guidelines, Standards and Health. Assessment of risk and risk management of water related infectious diseases. pp 207-227. Fewtrell L, Bardman J eds. IWA, Publishing, London.

[22] Prüss A, Kay D, Fewtrell L, Bartram J. Estimating the burden of disease from water, sanitation, and

[23] Hygiene at a global level. Environ Health Perspect. 2002 May; 110(5):537-42.

[24] Faria M, Javeria S, Muhammad SA. Bacteriological analysis of drinking water from services hospital Lahore and Services institute of Medical Sciences Lahore.Biomedical.2010; 26: 66-69.

[25] United States Environmental Protection Agency (USEPA). 1976. National Interim Primary Drinking Water Regulations Government Printing Office, Washington, DC. 